\title{
Open Price for Iran: The Bases for Reform
}

\section{Farzaneh Akrami}

Farzaneh.akrami@siswa.ukm.edu.my

\author{
Assoc. Prof. Dr. Sakina Shaik Ahmad Yusoff \\ kinasay@ukm.edu.my
}

\section{Assoc. Prof. Dr. Suzanna Mohamed Isa}

Faculty of Law, Universiti Kebangsaan Malaysia zie@ukm.edu.my

\section{Doi:10.5901/mjss.2015.v6n4s3p166}

\begin{abstract}
The rules of sale contract in many countries allow parties to conclude a contract without specifying the price at the time of formation. Such contracts are called open price sale (sale of goods) contracts and are of the needs of modern trade methods. As a result, parties enjoy the freedom to conclude their contract without contractual risks. The problem, however, is that under the Iranian rules on sale contracts, these possibilities do not exist. Such treatment by Iranian legislators on the issue of price in a sale contract has caused problems in national and transactional level. Adopting a doctrinal research method, the first aim of this study is to perform a review on the concept of open price term and the current Iranian law on this concept. The next objective is to explain the justifications for acceptance of open price term with regard to global evolutions, legal theories and Islamic theories and principles.
\end{abstract}

Keywords: Open price sale contract, Iranian law, Legal principles, Islamic principles, Global trade.

\section{Introduction}

According to Walker (1997) law is "a systematic body of coherent knowledge about the institutions, principles and rules regulating human conduct in the society." The relations between the individuals in a society are always based on the rules and regulations that are respected by that society. Iran, like other political societies, has its special customs, norms, moral rules and religious rules, all of which have affected the law of the country (Emami, 1996). The responsibility of regulating the relations among people, groups and countries, and of determining what is correct and just, is on the science of 'Law.' Today, there is rapid technological progress and a huge flow of unimaginable new products to global markets, coupled with the global appetite for the purchase of those products. Given this development, staggering levels of deals and contracts are concluded at every moment, throughout the world. Those developments compelled merchants to sell their products in order to avoid any loss, for example, by leaving the price open to be fixed at the time of delivery. In fact, contrary to the traditional form of sale contracts, the buyer and seller would not know exactly how much they are going to pay or receive in their contract. At the same time, however, they are sure that they will benefit from that contract. Nevertheless, in spite of all these developments and changes in world trade, there are still some rules that continue to follow traditional rules of sale contracts in which the parties are obliged to specify every single matter about consideration at the time of the conclusion of a contract. Merchants working under such legal system are likely to be imperiled as the courts will not support them, and will not enforce contracts concluded with their customers in an open price form (Darabpour, 1998). Through a doctrinal type of study, this paper has performed a review on the concept of open price and the Iranian law on open price term and justifications for necessity of recognition of this concept by the Iranian law. As the first step, the study aims to elaborate the mechanism through which an open price term in a sale of goods contract affects the parties' benefits in a positive way. The next objective would be a review on the current Iranian law on open price term and the existing dilemma as to necessity of acceptance of open price term. Following this, the justifications for acceptability of open price term from different aspect will be performed. To achieve this last objective, changes in global trade methods, and circumstances, legal theories that support open price term, and Islamic theories through which the 
importance of recognition of open price term is lighten will be studied.

\section{What is an 'Open Price'?}

Prosser (1932) describes open price by noting that the most important function of an open price term in a sale contract is to shift the risk caused by a fluctuating market from one of the parties to the other. A seller is always concerned about the fluctuation of the market price and that the price may decline in the future making him to receive much less than what his commodity is worth at the present moment. On the other hand, a buyer is always worried about the possibility that, before he buys, the market price will increase. The situation is similar to this when the contract is for future delivery, with the exception that, this risk may shift between the parties. However, most of the time, parties to a sale contract are unwilling to agree to this particular exchange of risks. They may wish to enter into a safe contract with the least contractual risks. In view of these conditions, there were attempts to deal with the transfer of risks, in a changing and fluctuating market, between the parties. Ultimately, this "has led to a variety of business arrangements by which, in a sale contract, the price is left open for future determination" (Prosser, 1932). In such circumstances, although the actual price of the goods by the time of delivery might be more or less than what they have assumed, that difference of the price can be compensated through the nonpayment to the insurance institutes in order to ensure the price fluctuations. In other words, in case that the price of the goods at the time of concluding the contract is $\$ 1$ and the parties are worried about contractual risks that may arise from price fluctuation, they will still benefit by leaving the price open. This is because if the price of the time of delivery is $\$ 0.99$ or $\$ 1.1$, the parties do not lose anything as in the normal method in which they fix the price at the initial stage, they would have to pay the same amount of $0.1 \$$ to insurance institutes in order to ensure the price fluctuation risks. To Murray (1984), the fact is that, in practice and as a result of new trade methods around the world, considerable amount of sale contracts are made in open price form. It is costly to present goods in the market place. There are costs of production and transportation. The amount of these costs, which are almost uncertain, will cause the market price of goods to increase or decrease. Thus, the final price of goods is usually uncertain. As Vold (1956-1957) explains, even the possible number of the buyers is not certain, especially according to the time and other different situations. There are many other features that make the market price of goods uncertain. He continues that "Boom, bust, war, peace, hope, fear, crisis, growth, decay, change; these may also affect general market fluctuations... a given fixed price thus may at the time of contracting seem too risky."

Parties to a contract intend to conclude their sale contract with open price term in order to avoid some risks. The contractors are business people and they mean to do so in order to benefit from the contract as much as possible. Therefore, open price is a key element that provides the possibility of performing less-risk transactions. Accordingly, some rules for open-price sale contracts are worth to be considered and studied in order to figure out the current condition of the legislations on it. Aside from what an open price term means economically, in law, what this phrase means is described through legislations. A combination of rules in Uniform Commercial Code (UCC) of the United States, Sale of Goods Act 1979 (SGA 1979) of the United Kingdom, and the United Nations Convention for the International Sale of Goods (CISG) show that a sale contract contains an open price term if nothing is said as to price; or the price is left to be agreed by the parties and they fail to agree; or the price is to be fixed in terms of some agreed market or other standard as set or recorded by a third person or agency and it is not so set or recorded. However, as the rules are different in the Iranian law, the attitude of the Iranian law and lawyers will also be reviewed.

\section{The Iranian Law}

The Iranian Civil Code contains all rules for sale contract. These rules start from article 338 as the first article under the title of 'sale contract'. While defining the sale contract, Article 338 provides that: "a sale contract consists of the transfer of the subject matter of the contract in return for a definite consideration". This Article is followed by another provision that emphasises the prohibition of an open price term. Article 339 stipulates that: "after determination of the object of the bargain and its price by the seller and buyer, the sale is concluded by offer and acceptance." It actually imposes that only after specifying the price, can a sale contract be concluded. Based on the Persian literature in which the Iranian Civil Code is written, the wording of Articles 338 and 339 define the vitality of determination of the exact amount of price and not the agreement of the parties on the totality of it without any knowledge about the exact amount of it. In fact, the wording of the Articles results in a complete prohibition of an open price term in the contract. The legal system of Iran is a civil law system and not a common law system. Thus, lawyers and legal scholars, especially judges who are in the position of enforcement of regulations, are totally bound by the words of the Articles in the code even if they have contrary personal ideas. 
The main source of the Iranian Civil Code is Islamic rules. Open price sale contracts are prohibited by Islamic rules and therefore, this is the Iranian law. The rationale for prohibition of open price term is the necessity of avoidance of loss to the parties. The Islamic principles of prohibition of any cause of loss and prohibition of a harmful sale contract are the main reasons underwhich the open price term is prohibited. This is because it is believed that lack of any knowledge on the price, and, to form a sale contract without being aware of the price that the buyer is obliged to pay and the seller is entitled to receive in return for the subject matter of the contract, will cause loss for the parties. However, a new trend of ideas that have questioned the workability and efficiency of this traditional rule based on today's circumstances has emerged. In fact, there are contrary ideas among some writers and legal experts. Some who are more engaged in the issues of development and changes in the world's methods of trade that require updated legislations, wish to reform such restricted rule existing in the Iranian rules. As Seifi (2013) remarks, although according to the traditional attitude of the Iranian law, ignorance about the exact amount of the price is a cause for the loss of the parties and therefore, such an agreement is void, however from an economic perspective, in some situations, it is even more beneficial for the parties to leave the price open to be fixed in future. Ashouri (2009) states that, there is a need for the economy of Iran to accept the open price term as a tool to enable the government to cope with the world's trade. He believes that the Iranian legislators need to revise the rules and pass suitable rules that answer the needs of the day considering the changes in the circumstances. Although Iran, at the governmental level, may act in the same way as other countries, i.e. adopt the open price term, when concluding international contracts such as oil contracts, it needs to reform its internal rules in order to permit the use of that term in domestic sale contracts as well. Any failure to adjust to the present global situation with the continuing technological advancements, and their effect on world trade, can disadvantageous to countries that continue to insist on traditional rules, and do not recognise an open price term in sale contracts.

Considering the practical consequences arising from current provisions in the Iranian Civil Code, as it was mentioned, the problem can be divided into two levels namely, national level and transactional level. For example, in manufacturing and industrial sectors, the closure of each of the active units causes the unemployment of many of the labourers and other employees. As such, the concepts of job safety, entrepreneurship and employment are seriously and negatively affected by insufficient rules. Rejection of the open price term can also negatively affect important aspects such as economic development, increase of national production, production of better quality and higher quantity, attraction of investors in the manufacturing affairs, long-term contracts, contracts between Iranian and foreign parties, and job safety. Through this rule, all open price sale contracts that might be concluded in the country are rejected by the courts. This means deprivation of people from forming any open price sale contract even though they find it beneficial and lucrative. A person can be the victim of bad rules in different ways.

\section{The Bases for Reform on the Law of Open Price in Iran}

This part of the research aims to study the workability and necessity of open price term from different aspects, namely, global trade methods and circumstances, legal theories that support recognition of open price term and Islamic principles and theories through which necessity of acceptance of open price term is elaborated.

\subsection{Global Perspective}

\subsubsection{New legal trend}

As Tarrant (2006) describes, in Woodside Offshore Petroleum Pty Ltd v Atwood Oceanics Inc ([1986] WAR 253), Kennedy J. acknowledged the existence of a more modern position when he remarked that it "may readily be accepted that, since the $19^{\text {th }}$ century, courts have taken a more lenient view to questions of uncertainty than previously." Earlier, in Cudgen Rutile (No 2) Pty Ltd v Chalk ([1975] AC 520), it was held that, "in modern times, the courts are readier to find an obligation which can be enforced" ([1975] AC 536). This is similar to the idea that influenced the decision in SVI Systems Pty Ltd v Best \& Less Pty Ltd ((2001) 187 ALR 302). In SVI Systems ((2001) 187 ALR 319-320), it was pointed out that when an incomplete contract is largely executed, "the agreement may be upheld by the implication of terms in order to avoid the injustice to a party who has performed but was unable to enforce the contract."

The modern trend in decisions on contracts has led courts to increasingly hold that a contract can exist and be valid even when there are some substantial gaps in the agreement made by the parties. As Furmston (2000) writes; "the fact that no price has been agreed might be good evidence that the parties had not completed a contract but it is clear that, in practice, people can make binding contracts without having agreed on the payment terms." This new flow of judicial opinion is opposite to the traditional position where the courts believed that there would be no existing and legally 
enforceable contract if the parties left essential terms of the agreement open to be determined and agreed upon in the future (Tarrant, 2006). The tendency to uphold agreements and contracts between parties has been extended to include preliminary agreements. Referring to the Western Australian case of Anaconda Nickel Ltd v Tarmoola Australia Pty Ltd ((2000) 22 WAR 101) and the recent trend of upholding contracts and even preliminary agreements between the parties, Allars (2000) states that:

\begin{abstract}
“...with increasing time pressures applying to commercial transactions, the enforceability of preliminary agreements, such as agreements in the form of letters of intent and heads of agreement, is an issue that courts are being required to consider more frequently. The decision of a court as to the enforceability of a preliminary agreement will invariably be based on "the facts of the particular case" and, as illustrated in the recent Western Australian Supreme Court decision in Anaconda Nickel Ltd v Tarnoola Australia Pty Ltd, the trend appears to be in favour of binding the parties to their "agreement."
\end{abstract}

Schmidt (1983) points out that what happens in most preliminary agreements is that the parties have reached a stage where they are certain that they want to conclude the contract, and decide that their agreement has already clarified and realised certain factors and elements sufficient to be considered as a definitive contract, even when other elements of the contract remain under discussion. Such a preliminary contract should, therefore, be binding on the parties (Tarrant, 2006). The modern approach, thus, is that the courts will fill the open terms in the agreement, including the open price term, in appropriate circumstances (Gleeson, 1985). In fact, under this approach, the courts look at the gaps in a more "constructive manner" (Tarrant, 1930-1931). Ayres and Gertner (1989) believe that, whether the courts should complete the incomplete parts of the contract or not, depends on why the parties have left them open. Baird (1990) argues that if the parties do not consider some factors that are supposed to be included in their contract, then it is the law of contract that should do it for them.

\title{
4.1.2 Certainty; freedom of contract; sanctity of contract
}

According to Allars (2000), the first issue that the courts usually consider in a case where it is to be determined whether a contract is enforceable or not, is the general principles of certainty; how complete parts and terms of the contract are, and whether the parties had intended to create a legal obligation. A fact that emerges from Anaconda Nickel Ltd $v$ Tarmoola Australia Pty Ltd ([2000] WASCA 27; 22 WAR 101) is that the time pressures on commercial transactions have created a need for the enforceability of even preliminary agreements; an issue that the courts will frequently have to grapple with.

To Prosser (1932), the principal legal obstacle to an open price contract is the requirement of certainty. The idea is that uncertainty causes losses to the parties, and this is not what is expected of a good rule. However, the fact is something else ie. bad law, which imposes restrictions that are unnecessary to preserve harmony, or tends to create discord, and is inexpedient to the promotion of prosperity. Therefore, opposed to this requirement of certainty, is the obvious fact that, in all open price contracts, there is an intention to make a deal. The agreement is made by business people, and it is meant to accomplish something. It is not to be supposed that they have gone through the pain of making a contract with the intention that it shall be of no effect.

Vold (1930-1931) offers a very clear and rational reason why an open price contract should be validated and considered not harmful to the parties. He explains that, "when [...] parties deal with each other at arm's length, both being equally competent to contract, it is ordinarily assumed that the parties themselves at the time of contracting are the best judges of what is likely to be for their advantage." Berry (2007) points out that commercial relationship have become more complex and interlocked over the last century. Therefore, the law has to evolve in order to keep pace and remain useful. He states that, "contracts that previously would have been voided for indefiniteness became permissible, even when they left out key terms, including price." As to an open price term, Vold (1956-1956) stresses that, "it often happens, however, that at the time of contracting, a price definitely fixed in terms of money is too rigid to accord with the business needs of one or the other party for the occasion." The vexed question, therefore, is why should the law limit the parties' will even when they are thoroughly aware of their interests in entering into such contracts?

The theories of freedom of contract and sanctity of contract are two notable concepts that stop the courts from readily nullifying contracts. Moxon (1945) states that:

"Sanctity of contract is a fundamental doctrine in industrial and commercial society. Of course, [...] it is older, far older, than the industrial era. It is the fine flower of the doctrine of the supremacy of the law in human affairs the doctrine which, when transplanted to America, flourished there as never before. It is not too much to say that without the doctrine of sanctity of contract the remarkable material development of the Western Hemisphere could not have taken place."

The theory of freedom of contract provides that as long as social peace and order is not disturbed, people can 
conclude any contract with any provision that they believe is beneficial to them. When the parties decide to form such a contract, they have considered their own benefits and they wish to make this contract. Thus, preventing them from forming their preferred contract that is beneficial to them is clearly against the theory of freedom of contract. In line with this, the concept of sanctity of contract provides that contracts between the parties that have formed them with their satisfaction should be respected and not be nullified.

\subsubsection{Global trade changes}

Freeman (1988) states that "Technological change is, without any doubt, 'a fundamental force in shaping the patterns of transformation of the economy'." In such circumstances old and restricted rules will be unenforceable. Today, there is rapid technological progress, and a huge flow of unimaginable new products to global markets, coupled with the global appetite for the purchase of those products. Through such development, and the non-stop, ultra-fast rate of data transfer enables even people in the most remote parts of the world to benefit from all developments. In fact, staggering levels of deals and contracts are concluded at every moment, throughout the world. Global changes add to the necessity for the reconsideration of the present rules. Governments cannot stay equal to their counterparts in other parts of the world if they insist on the national policies of ancient times. Krawjski (2003) observes that, "while there is not much agreement about the exact dimension of "globalisation" ... there seems to be a general consensus that the dynamics of global and regional economic systems affect the efficiency of national policies significantly." Self reliance is the goal of every country, but this cannot be attained if the existing rules are old, restrictive and inadequate. The Iranian Civil Code that has adopted Shari'ah principles emphasises the necessity of the specification of the price at the time when the parties are concluding a sale contract. At the same time though, in view of the expansion in global economic relations, the amendment of the domestic rules, on the one hand, and the accession to international conventions such as the CISG, on the other, are highly desirable (Darabpour, 1998). As Darabpour (1998) mentions, open price has been practised in many countries for years and is also widely practised in international trade. The large number of sale contracts that have already been concluded with open price term throughout the world shows that not only is it beneficial, it is also a vital need for modern commercial transactions. Therefore, the idea that an open price term will cause loss to the parties can no longer be supported by logic. The adoption of new and efficient rules is both a need and a serious obligation for national legislative bodies. Krawjski (2003) explains that national rules should not be isolated or avoid coordinating with the modern needs of international trade.

Leslie (2004) describes the effect of open price in preventing economic fraud. According to him, a look into the history of trade associations will reveal that they have made some trust-facilitating devices. Price transparency is included in these trust-facilitating devices in order to stabilise cartels. He mentions how new rules give attention to the issue of open price, and, in fact, how experts are well acquainted with the effective role of the concept in a healthy economy. As he puts it:

\footnotetext{
"...before the NRA codes, cartels were plagued by cheating. But the NRA essentially created government-endorsed cartels. NRA codes included a raft of cartel-stabilizing dictates, including prohibiting discounts, condemning sales below set prices, constraining output, and requiring open prices. [...] The NRA regime solved the distrust problem that had plagued many earlier cartels. The NRA permitted hundreds of industries to adopt open price agreements. Several others were allowed to engage in base-point pricing. The codes ensured greater transparency by implementing open price systems and monitoring (Leslie, 2004)."
}

This is one example of the many different cases in which an open price system has been adopted.

\subsubsection{Globalisation and liberalisation}

Krajewski (2003) notes that a common topic in today's political and academic debates is that the significance of the nation-state in the period of globalisation and post-nationalism is declining rapidly. Global and regional, political, economic, social and cultural integrations seem to make it difficult to pursue national policies autonomously. The concept of 'liberalisation,' which is one of the key issues in economic studies, is also a good illustration of the direction in which the world is heading.

Globalisation and liberalisation are closely related to each other. Trade liberalisation, as Michaely (2004) explains, is one of the main issues in the field of commercial policy. Thus, the subject of trade liberalisation and the conclusion of preferential trade contracts, as a process of liberalisation, has been under consideration in recent years. In addition, Krajewski (2003) explains that liberalisation is a process through which a competitive market environment and a wider 
market are introduced. However, in order to bring about such a process, existing barriers to market entry and competition need to be eliminated. He continues that there are two levels of liberalisation: domestic liberalisation and international liberalisation such as the liberalisation of trade. Domestic liberalisation engenders competition in the economy of the country concerned, and the same is true for international liberalisation in the international economy. Any improvement in a country will have a reverberation effect across different sectors in the domestic economy. These rapid global changes are undeniable reasons for the legislators of each country that has economic needs to pass rules, which, while maintaining order in society, are in tune with the evolving global trends and meet the emerging needs of the world.

\subsubsection{Unification and uniformity of laws}

The concepts of unification, uniformity and harmonisation of laws have raised considerable issues in the world of legal studies in recent decades. With regard to the concept of Global Village, when the relation between the countries expands, the need for a uniform law to govern their affairs will be an issue. This is because of the difficulties that occur as a result of different legislation and rules. Any attempt toward amendment of domestic or international laws and any step to modify the rule through adopting the positive points of the similar laws can be considered as steps toward unification, uniformity and harmonization (Soronen, 1980-1981).

The sale contract, as Ferrari (1995-1996) states, is "the pillar of the entire system of commercial relations." Thus, it was considered necessary to create a uniform law for sale contracts that would overcome the problems encountered by merchants as a result of national borders. In fact, national borders, as he observes, constitute "an obstacle to economic relationships which constantly increase among citizens of different countries; an obstacle above all for the enterprises that are involved in international commerce and that acquire primary resources or distribute goods in different countries which all have different laws." Ferrari also points out the reality of the unification of international law in a clear way. According to him, "in order to create uniformity, it is, however, not sufficient to create and enact uniform laws [...] since the same uniform law can still be interpreted and, thus, applied differently by the judges of different countries." World trade is improving rapidly due to the recent technological advancements including global and instantaneous means of communication. There is a considerable group of people that rely on these tools in order to conduct their commercial affairs. This has led to considerable levels of trade between parties from different countries. In turn, this has precipitated some difficulties. Under which law should these contracts be governed? Unfortunately, the rules relating to this question and the issue of choice of law differ from country to country, rendering the whole issue difficult to tackle. In order to obviate the existing uncertainty as to which rules will govern such contracts, considerable attempts have been made toward the unification and harmonisation of the laws existing worldwide.

\subsection{Islamic Principles}

Islam is a flexible religion, and opposes any loss, or harm to people. According to Morteza Motahari (1994), it is an Islamic tenet that Muslims should try to make Islamic rules cope with the needs of the day. He explains that the needs of the time are, in fact, the needs of the society; people are equipped with the power of their thought, the power of invention and the power of authority. As cAbdullah Jalil (2006) explains, from an Islamic perspective, the concept of maslahah (public interest; public welfare; utility) and doctrine of Maqasid (objectives) are two necessary tools to be referred to for the purposes of developing choices and preferences. Within the Islamic framework, these two concepts have an important effect on matters such as project evaluation procedures. According to Al-Ghazali (1998), maslahah is a concept that shows the important factors that should be taken into consideration in Islamic affairs for the benefit of the people. He believes that maslahah is the "preservation of the religion, life, mind, offspring and wealth." He states that, "everything that leads to the preservation of these five foundations is considered maslahah, and everything that leads to the disruption of these foundations is mafsadah (Loss; Corruptivity; Disadvantage), and its removal is maslahah." According to Habib Ahmed (2006), "a large literature has discussed the role of law and legal institutions in financial development." To him, "one of the most important determinants of financial development is adaptability of law to changing conditions." Adaptability underlines the ability of legal traditions to develop and change. A vital element to the development of the Islamic financial system is the adaptability of the law to changing circumstances. One of the factors on which the growth of the financial sector depends is the efficiency with which the law can adapt to changing circumstances. One of the characteristics of Islam is that Islamic scholars can bring its rules up to date without overreaching the boundaries or transgressing the fundamental principles of the religion (Motahari, 2002). Maulana Waheeduddin Khan (2012), has this to say: 
"The intellectual development of the present day Muslims has practically stopped. The reason is that they have become used to following blindly whatever scholars have written in the past. The mujtehadana or independent rational way of thinking has ended, as if it is an evil. Such people lag behind the other nations in knowledge and intellect. The main reason of the failure of Muslims is that while they think about what is right and what is wrong, they fail to see what is possible. All their unnecessary sufferings are the result of rushing for something that they consider right without the practical consideration of what is possible. They fail to follow the gradual process adopted by the Prophet, of changing the minds before changing the system. ljtehad is not merely an intellectual process."

Motahari (2002) suggests a good example in that regard. In the past, human blood had no use, and, therefore, to buy and sell it was illegal (haram). However, today, according to new developments in medical science, human blood is valuable, and scientists and medical practitioners use it in saving lives. Hence, it is now legal (halal) to buy and sell human blood. Moreover, it is even necessary to have such deals since Islam is against any kind of harm or loss to the people. Islamic law was created following the advent of Islam. There are certain essential goals that Islamic law is concerned about. According to Habib Ahmed (2006), the total goal of the Islamic law is to promote the welfare (Masalih) of mankind. In general terms, the objective of Islamic rules covers aspects such as the provision of growth and justice. And in specific terms, it relates to the preservation and protection of religion, life, reason, progeny and property. Thus, meeting and protecting one or several of these goals is supposed to be the objective of each of the Islamic rules. The doctrine of Zarurah (exigency) is another respect in which the necessity of the open price term can be felt. The problem can take cover under the doctrine of Zarurah provided by Shariah, in order to give relief when the other alternative is harmful or fatal.

Traditionally, Islamic rules are divided into two: transactions or dealings (Muamalat), and devotional matters (Ibadat) (Kamali, 2000). There are, however, some differences between the rulings relating to these two divisions. Based on Shari'ah principles, as to the devotional matters, if something is not validated by Shari'ah, it is thereby prohibited. Here, the principle is that the permitted acts are clearly stated and anything other than those that are expressly permitted or any conversion of devotional rules is forbidden. However, the principle is different, indeed, opposite with regard to transactions and business. In this category, everything is permitted other than those explicitly forbidden. This is called the principle of permissibility (Ibahah) (Habib Ahmed, 2006). Shari'ah has clearly spelt out the prohibitions, and it is important to stress at this point that the list of those prohibitions ought not to be expanded because it is only Shari'ah that can determine what is prohibited, or permitted. Regarding this category, gharar (loss) is one of the prohibited items. As Kamali (2000) explains, there is another difference between the two categories of Islamic rules. While it is not possible at all to change the rituals and rites of devotional matters, the ruling on muamalat [transactions and deals] can be moderated and adjusted through the process of ijtihad. Accordingly, although the fundamental principles or doctrines of business transactions are specified in Shari'ah, the need to have practicable rules in trade transactions has created the figh-al-muamalah (jurisprudence of transactions) so as to make the principles suit the prevailing circumstances in different places and times. Kamali (2000) adds that the necessary tool for new rulings is an appreciation of the effective rationales (hikmah) and causes (illah) of the original principles and rules, together with the importance of the benefits (maslahah ) and interests of humankind. The important elements and underlying issues to be considered in framing new Islamic rulings and law are the goals (maghasid) of Shari'ah and the benefits of humankind that it aims to provide.

As Habib Ahmed (2006) points out, "the traditional nominate contracts in their pure forms do not have the features that can cater to the needs of the contemporary financial markets and institutions. Thus, the challenge for Islamic law was to adapt to this new financial structure to enable financing through markets and intermediaries." Islamic law had to establish a new and efficient set of financial contracts comprehensive enough to respond to the contemporary financial structure and needs. As mentioned earlier, there are many contemporary issues that have no anchor in the past and in the traditional rules. An example could be the subject of the open price sale contract, which is considered to be a prohibited contract because there is the risk of gharar (loss) to the parties. In this regard, a considerable evolution has taken place in the beliefs of Islamic scholars. Kamali (2000) argues that, "if new technology can eliminate gharar in the contract, then it may be reconsidered. He asserts that the implementation of contemporary futures contract removes gharar, the very basis for the prohibition of these contracts, and, as such, they ought to be allowed."

As Syed Hashim Ali Akhter (2013) asserts, Najatullah Siddiqi, the Faisal Award winner for his work on Islamic economics, had this to say in respect of Islamic banking and the needs of the modern world, at the annual meeting of the Islamic Society of North America in September 2001: "Shariah is not a body of fixed written rules but a continuing process. Zarurah is also part of the Shariah and is a continuous and dynamic process. Islam has a positive attitude toward wealth, a life-supporting thing." Syed Hashim Ali Akhter states that:

"...there are no answers to the problems of the modern world in the old literature, including banking. In his [Najatullah 
Siddiqi] consultation with the orthodoxy he found them ignorant of economics, co-operative law and modern finance. Forty years back there was not a single person in the world of Islam with good knowledge of Arabic, good English and modern subjects. The answers by Ulema [scholars] leave much to be desired. The days of fatwas based on past books are gone. Now a life-long preparation is needed for all relevant subjects and a lot of assistance from others is necessary. No money is spent in Muslim countries on fundamental research. We have not yet found an alternative to banking with the necessary transparency, competitiveness and the interest of the consumer."

The fact that is understood from the above discussions is that the aim of amendment to the rule and acceptance of open price is not against any legal or Islamic theories. The above theories can be looked at with a wider perspective. This will demonstrate the extended scope that can be covered by such theories and any resistance against modification of traditional thoughts will deprive human beings from possibilities of development and progress to live a better life.

\section{Conclusion}

The existing Iranian rules are highly affected by the Islamic law. According to the Islamic law, open price term is rejected based on some maxims and principles. The principle of prohibition of any causes of loss and the principle of prohibition of harmful sale contract are the bases for such rejection. In addition, the concept of certainty is a general legal concept that has traditionally prohibited open price term even in countries that have now recognised this concept. However, through this study, it is explained that not only based on the above theories themselves, but also based on some other Islamic and legal theories and principles, the acceptance of open price term is vital and necessary. Islamic principles such as maslahah and zarurah are the Islamic theories, together with the above mentioned maxims of prohibition of any causes of loss and the principle of prohibition of harmful sale contracts can prove the necessity of open price term. In addition, the legal theories of freedom of contract and sanctity of contracts together with the concept of certainty are other theories under which open price term is found out to be an important concept to be accepted in sale contracts.

\section{References}

Ahmed, Habib. (2006). Islamic law, adaptability and financial development. Islamic Economic Studies, 13, 79-80.

Al-Ghazali, M. (1998). Al-Mustasfa Min 'IIm Al-Usul. Beirut: Dar al-Kutub al-Islamiyyah.

Allars, V. (2000). Anaconda Nickel Ltd V Tarmoola Australia Pty Ltd - the extraordinary lengths the courts will go to in order to bind parties to their agreement [Notes]. University of Notre Dame Australia Law Review, 2, 71-76.

Anon. (1984). Unification and Certainty: The United Nations Convention on Contracts for the International Sale of Goods. Harvard Law Review, 8, 1984-2000.

Ashouri, H. (2009). A brief note on the economy of Iran. Dynamic Economy, 11, 14-27.

Ayres, I. \& Gertner, R. (1989). Filling gaps in incomplete contracts: an economic theory of default rules. Yale Law Journal , 99, 87-130.

Baird, D. G. (1990). Self-interest and cooperation in long-term contracts. Journal of Legal Studies, 19, 583-596.

Berry, D. C., Byers, D. M. \& Oates, D. J. (2007). Open price agreements: good faith pricing in the franchise relationships. Franchise Law Journal, 147, 45-56.

Darabpoor, M. (1998). Open price. Tahghighat Hoghooghi, 21-22, 221-283.

Emami, S. H. (1996). Civil Law. Tehran: Eslamiyeh.

Ferrari, F. (1995-1996). Specific topics of the CISG in the light of judicial application and scholarly writing. Journal of Law and Commerce, 15, 1-126.

Freeman, C. (1988). Structural crises of adjustment, business cycles and investment behaviour. Dosi, G., Freeman, C., Nelson, R., Silverberg, G. \& Soete, L. (Eds). Technical Change and Economic Theory. London: Pinter.

Furmston, M. P. (2000). Sale \& Supply of Goods. London: Cavendish Publishing Limited.

Gleeson, M. (1985). Contractual uncertainty. Australian Bar Review, 1, 74-83.

Jalil, A. (2006). The significances of Maslahah concept and doctrine of Maqasid (Objectives) Al-Shari'ah in project evaluation. Journal of Muamalat and Islamic Finance Research (JMIFR), 3, 171-202.

Kamali, M. H. (2000). Islamic Commercial Law: An Analysis of Futures and Options. Cambridge: The Islamic Texts Society.

Krajewski, M. (2003). National Regulation and Trade Liberalization in Services: The Legal Impact of the General Agreement on Trade in Services (Gats) on National Regulatory Autonomy. Netherlands: Kluwer Law International.

Leslie, C. R. (2004). Trust, distrust, and antitrust. Texas Law Review, 82, 515-680.

Maulana Waheeduddin Khan, (2012), [Online] Available: http://www.muslimpersonalfinance.org/riba-interest-or-usury.html.(09.12.2012)

Michaely, M. (2004). Trade Liberalization and Trade Preferences. London: Ashgate.

Motahari, M. (1994). Last Prophesy. (6th ed.). Tehran: Sadra.

Motahari, M. (2002). Islam and Present Needs. (1st. ed.). Tehran: Sadra.

Murray, D. E. (1984). The 'open price' sale of goods contract in a worldwide setting Franchise Law Journal, 89, 491-500.

Prosser, W. L. (1932). Open price in contracts for the sale of goods. Minnesota Law Review, 16, 733-790. 
Schmidt, J. (1983). Preliminary agreements in international contract negotiation. Houston Journal of International Law, 6, 37-47.

Soronen, V. L. (1980-1981). Amendment to Article XVI, 15 of the Texas Constitution: greater uniformity among the community property states. South Texas Law Journal, 21, 239-248.

Syed Hashim Ali Akhter, (2013), [Online] Available: http://www.pws.gov.nt.ca/pdf/publications/ProcurementGuidelines09/9.3\%20 Contract\%20Law.pdf. (12/10/2013)

Tarrant, J. (2006). Preliminary agreements. University of New England Law Journal, 3, 151-186.

Vold, L. (1930-1931). Open price agreements in the sale of goods. Temple Law Quarterly, 5, 208-214.

Vold, L. (1956-1957). Open price in sales and marketing of goods. Texas Law Review, 35, 637-646.

Walker, D. M. (1997). The Scottish Legal System, an Introduction to the Study of Scots Law. (7th. ed.). Edinburgh: Sweet \& Maxwell. 